\title{
Article
}

\section{Indoor living plants' effects on an office environment}

Smith, Andrew James, Fsadni, Andrew and Holt, Gary David

Available at http://clok.uclan.ac.uk/18555/

Smith, Andrew James, Fsadni, Andrew ORCID: 0000-0003-3047-2714 and Holt, Gary David (2017) Indoor living plants' effects on an office environment. Facilities, 35 (9/10). pp. 525-542. ISSN 0263-2772

It is advisable to refer to the publisher's version if you intend to cite from the work. http://dx.doi.org/10.1108/f-09-2016-0088

For more information about UCLan's research in this area go to http://www.uclan.ac.uk/researchgroups/ and search for < name of research Group>.

For information about Research generally at UCLan please go to http://www.uclan.ac.uk/research/

All outputs in CLoK are protected by Intellectual Property Rights law, including Copyright law. Copyright, IPR and Moral Rights for the works on this site are retained by the individual authors and/or other copyright owners. Terms and conditions for use of this material are defined in the policies page.

\section{CLoK}

Central Lancashire online Knowledge www.clok.uclan.ac.uk

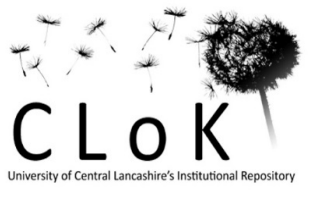


3

\title{
Indoor living plants' effects on an office environment
}

\section{Structured Abstract}

\author{
Purpose \\ The use of indoor living plants for enhancement of indoor relative humidity and the general environment of a \\ large, modern, open plan office building; are studied using a mixed-methods paradigm.
}

\section{Design/methodology/approach}

The quantitative element involved designated experimental and control zones within the building, selected using orientation, user density, and users' work roles criteria. For a period of six months, relative humidity was monitored using data loggers at 30-minute intervals and volatile organic compounds (VOCs) were measured using air sampling. Qualitative 'perception data' of the building's users, were collected via a structured questionnaire survey among both experimental and control zones.

\section{Findings}

Study findings include that living plants did not achieve the positive effect on relative humidity predicted by (apriori) theoretical calculations; and that building users' perceived improvements to indoor relative humidity, temperature, and background noise levels, were minimal. The strongest perceived improvement was for work environment aesthetics. Findings demonstrate the potential of indoor plants to reduce carbon emissions of the [as] built environment, through elimination or reduction of energy use and capital-intensive humidification airconditioning systems.

\section{Originality/value}

The study's practical value lies in its unique application of (mainly laboratory-derived) existing theory in a reallife work environment.

Keywords: Indoor air quality, Comfort, Temperature, Volatile organic compounds, Living plants, Relative humidity

Article classification: research paper

\section{Introduction}

Indoor air quality (IAQ) of commercial and domestic buildings has been widely researched over the past three decades. Studies have focussed on aspects such as respiratory irritants, for instance, nitrogen and sulphur dioxides (Taylor, 1996; Chao, 2001; Meininghaus et al, 2003; Baur et al, 2012); carcinogens such as asbestos (Reynolds et al, 1994; Latif et al, 2011; and other volatile organic compounds (VOCs) such as formaldehyde (Wolverton and McDonald, 1982; Ekberg, 1994; Meininghaus et al, 2003; Zuraimi et al, 2006; Rios et al, 2009; Salonen et al, 2009). Research has also investigated optimum percentage relative humidity $(\% R H)$ of indoor air (Wyon et al., 2002; Wolkoff and Kjaergaard, 2007; Wan et al., 2009); this being the ratio of percentage water vapour held within it to its equivalent 'saturation level' at a given 
temperature. This study extends these concepts in terms of their being influenced by the introduction of indoor living plants, in a large modern building. The building users' perceptions of their internal environment in relation to these plants, are also considered.

Typically, humidity is not classified as an indoor air contaminant (Nagda and Hodgson, 2001). Nonetheless, many studies (for example, Wyon et al., 2002; Wolkoff and Kjaergaard, 2007; Wan et al., 2009) and building design guides (CIBSE, 2005; 2006), recommended that indoor $\% R H$ should be in the range of $40-60 \%$. Beyond these parameters there are negative health implications for building inhabitants as described in the literature review later; and for levels above the maximum recommended $R H$ value especially, there are additional risks of building (components') damage. Examples of this include material expansion, salt staining, corrosion, pattern staining, interstitial condensation, and fungal growth (CIBSE 2005; Hetreed, 2008; Oxley and Gobert, 2011).

Mechanical humidity control is available, but the use of living indoor plants for this purpose is much less researched or understood (existing studies include Costa and James, 1995; Wolverton and Wolverton, 1996). The primary aim of this study therefore, is to investigate the potential of plants to supplement indoor air relative humidity $(R H)$, during cold winter months. This is important because decreasing air temperature reduces the ability of air to hold water vapour. Hence, as cold air from ventilation is heated up to indoor temperature, its ability to retain water vapour increases, resulting in a proportionate decrease in its relative humidity. This could lead to prolonged periods of below recommended indoor $\% R H$ and the resultant associated problems such as occupant discomfort (addressed in the literature review below).

The study was undertaken empirically, where indoor $\% R H$ was measured over a period of six months in a large (approximately 10,300 $\mathrm{m}^{2}$ gross floor area), modern 'atrium design' office 
building. The building was selected as a case study, because its facilities management were investigating low carbon and sustainable methods of humidification, during the winter months. An objective linked to this aim, was to compare these empirical data with those of theoretical a-priori calculations. The latter 'predicted' the humidification effect of indoor plants as a product of their plant transpiration rates and foliage area, to identify an 'ideal' indoor planting density. The building users' perceptions of (the introduction of) indoor plants were sampled in relation to humidity, temperature, noise, light, space, aesthetics, and working environment privacy.

\section{Literature review}

Indoor relative humidity $<30 \% R H$ is only acceptable for limited periods of time, otherwise, building occupants can become prone to allergies and respiratory illnesses due to dust and other airborne particles (CIBSE, 2006). At significantly low levels of humidity, Bron et al. (2004) reported a change in the precorneal tear film in humans' eyes, that results in discomfort (dry eyes), while Doty et al. (2004) reported sensory irritation of the upper airways. Wyon et al. (2002) identified that human skin exposed to $15 \% R H$ was significantly drier than the same skin exposed to $35 \% R H$ and associated this kind of health symptom, with the classic definition of sick building syndrome.

More recently, Wolkoff and Kjaergarrd (2007) confirmed that the health implications of indoor humidity are complex. Further, that these have not been widely investigated due to the complicated influence of $R H$ on the combined impact of VOCs and other indoor air contaminants. Low humidity levels are also associated with susceptibility to electrostatic shocks. Human body voltage is a function of indoor air such that a decline in $\% R H$ yields an 
increase in body voltage (CIBSE, 2006) - a situation exacerbated in buildings with a combination of underfloor heating and carpet flooring due to sustained dryness of carpets.

Higher $R H$ levels are associated with poor ventilation and/or significant evaporation from moisture sources (such as bathrooms, kitchens, and indoor plants). High humidity can also lead to surface (or interstitial) condensation on (or within) external walls and other building fabric whose temperature $\leq$ the prevailing dew point. Mould, microbial, and house dust mite growth often result from this (CIBSE, 2005). In colder climates such as those typical in Northern Europe, buildings where no humidification equipment is installed can experience prolonged periods where indoor $R H$ falls below the recommended lower value of $40 \% R H$. This happens because the ability of air to hold water vapour decreases commensurate with declining air temperature. Resultantly, as cold ventilation air is heated to indoor temperature, its enhanced ability to retain water vapour means that its $R H$ decreases proportionately.

Mechanical humidification equipment (MHE) can help counter this situation, but in most European Union countries, indoor $\% R H$ levels are not defined in statute so (due to financial implications), most buildings do not make use of such. That is, mechanical humidification is typically controlled by the heating and injection of steam into supply air (CIBSE, 2005); which calls for significant MHE capital outlay and high running costs. Humidification also has a negative impact on a building's carbon 'footprint' because for each $10 \mathrm{~kg} / \mathrm{hr}$ of water vapour produced, circa $7.22 \mathrm{kWh}$ of gas is consumed as fuel, producing $1.61 \mathrm{kgCO}_{2}$ (Department for Environment Food and Rural Affairs, 2015).

IAQ is also a function of indoor carbon dioxide $\left(\mathrm{CO}_{2}\right)$ concentration levels (Lee et al., 2002). Humans exhale $\mathrm{CO}_{2}$ so indoor spaces are characterised by higher concentrations of $\mathrm{CO}_{2}$ than 
are found in outdoor air. Usha et al. (2012) reported that high $\mathrm{CO}_{2}$ concentrations are associated with poor IAQ and, that this could lead to health issues such as headaches, mucosal irritations, slower work performance, and increased employee absence. For this reason, CIBSE (2006) recommended a fresh air supply in the range of 5-8 litres per second per occupant, the aim being to sustain an internal $\mathrm{CO}_{2}$ concentration in the range of 1,000 to $1,350 \mathrm{ppm}$.

Other pollutants affect IAQ, including certain building materials, furnishings, and equipment - the most pertinent of which are classified as VOCs. Zuraimi et al. (2006) confirmed that indoor VOC levels are typically higher than outdoor levels. VOCs can negatively affect occupants' health by increasing the occurrence of cutaneous and mucous membrane symptoms associated with sick building syndrome (Ekberg, 1994). The World Health Organisation (2010) recommends that indoor levels of formaldehyde and total VOCs should be lower than 100 and $300 \mu \mathrm{g} / \mathrm{m}^{3}$ respectively.

\subsection{Indoor plants in office buildings}

The ability of indoor plants to counteract indoor air polluting chemicals was first evidenced in the early 1980s and much of this research was undertaken by NASA (Wolverton et al., 1989). Experiments found that soil acts as a sink for removing airborne VOCs such as formaldehyde (Wolverton and McDonald, 1982; Wolverton et al., 1984) and benzene and carbon monoxide from closed experimental chambers (Wolverton, 1986). These studies also reported a significant reduction in air pollution, from within a modular structure that replicated an energyefficient building. It was found that both plant leaves and their roots help in the air purification process (Wolverton, 1988). 
142 Godish and Guindon (1989) built on these early studies, and examined the removal capabilities

143 of plants under dynamic conditions where formaldehyde was continuously generated and

144 released with varying emission rates. They found formaldehyde reduction rates of between 29-

$14550 \%$. Wolverton and Wolverton (1996) later showed how different plants grown in the same

146 soil had significantly different formaldehyde removal abilities. Plants that culture large numbers of gram-negative bacteria (such as Pseudomonas) on or around their roots, are more effective at VOC removal than those that culture predominantly gram-positive bacteria. Giese et al. (1994), added support to the idea of air decontamination by plants. In their study, spider plants were put in contact with formaldehyde over a 24-hour period and this was removed by the plants to below detection limits, from the atmosphere of an experimental glass chamber within five hours. They suggested that a single $300 \mathrm{~g}$ spider plant (Chlorophytum comosum) could 'detoxify' a $100 \mathrm{~m}^{3}$ room in six hours. Another study indicated that efficacy of purification increased with greater numbers of plants, and that purification took longer with increasing molecular weight of the chemical being absorbed (Oyabu et al., 2003).

Recent experimental work has considered the uptake rates of various plant species concerning specific VOCs, finding for example, that Dracaena sanderiana is highly efficient at Benzene removal (Treesubsuntorn and Thiravetyan, 2012). Of 12 species tested, Sansevieria trifasciata had the highest toluene removal rate, while the highest ethylbenzene removal rate was by Chlorophytum comosum (Sriprapat et al., 2014). Evidence based on test chamber experiments have also shown that at light $\mathrm{CO}_{2}$ intensities (as commonly found indoors), hydroculture plants are more effective at $\mathrm{CO}_{2}$ reduction than those grown in a traditional potting mix (Irga et al., 2013). (Hydroculture is where plants are grown in a static closed container system, containing an inert growth medium such as perlite or expanded clay, and saturated with a controlled nutrient solution). However, the rate of hydroculture VOC removal was found to be slower 
than for traditional potting mix plants. This study also highlighted the need to expand these kind of chamber experiments, to real indoor spaces (Irga et al., 2013).

Living plants such as Rhapis palms and Marantas (which require regular misting) or plants with a high moisture content, can benefit offices with sustained levels of low indoor air humidity (Costa and James, 1995). Such plants can increase the $R H$ of a non-air-conditioned building by about $5 \%$, although the planting density required to achieve this, would be higher than 'normally' provided for a commercial office environment (ibid.). Wolverton and Wolverton (1996) suggested that due to transpiration, plants may be used instead of (or as a complement to) mechanical humidifiers to supplement humidity levels in homes and offices. During photosynthesis, plants absorb $\mathrm{CO}_{2}$ from the atmosphere through their stomata (tiny openings on the leaves), while the roots absorb moisture from the soil. Chlorophyll and other tissue in the leaves absorb radiant energy from light sources, which is used to split water molecules into oxygen and hydrogen. Plants use the hydrogen and $\mathrm{CO}_{2}$ to form sugars while oxygen, a by-product of photosynthesis, is released into the atmosphere (Wolverton, 1986).

Smith et al. (2011) reported a plant trial in an open plan office where short-term sickness absence was reduced in the planted experimental area, by approximately half of that in a control planting and workers' sickness absence.

Evidence also suggests that indoor plants can help reduce ambient noise levels, although it is unlikely they would act as efficiently as dedicated sound attenuation construction solutions. 
192 Costa and James (1995) contended that plants might achieve acoustic quieting by absorption; as did Freeman (2008) who suggested plants may absorb, diffract, and reflect sound dependent upon their characteristics; such as size, shape, container, top dressing, compost, and positioning. Indeed, indoor planting density commensurately increases noise reduction efficacy (Costa and James, 1995). Considerable environmental psychology research has studied the role of nature. For example, outdoor natural environments and vegetation have been shown to provide several psychological benefits including positive feelings (Sheets and Manzer, 1991), environmental awareness (Lutz et al., 1999), reduced driver frustration (Cackowski and Nasar, 2003), reduced crime (Kuo and Sullivan, 2001) and enhanced cognitive functioning in children (Wells, 2000).

While 'completely natural' office building environments may not be fully achievable, research confirms that natural environment views from windows can provide restorative effects, from mental fatigue (Kaplan, 1993) and job stress (Leather et al., 1998). Bringslimark et al. (2011) assessed whether office workers compensate for a lack of natural views and found that those in windowless offices were approximately five times more likely to bring plants into their workplace. Indoor plants at work have also been associated with improved attentiveness (Lohr et al., 1996), better task performance (Shibata and Suzuki, 2001) and a reduction of sick building syndrome symptoms (Gou and Lau, 2012). Additionally, active interaction with indoor plants can reduce physiological and psychological stress (Lee et al., 2015).

\section{Methodology}

A mixed-methods study was used that employed theoretical humidity and power consumption analysis, physical data logging, and a perception questionnaire survey. This methodology is 
described in terms of: i) the building, ii) theoretical design; iii) planting arrangements; iv)

217 relative humidity; and v) employee perceptions.

\subsection{The case study building}

220 The building was a Local Council Head Office in Southern England, responsible for a population of c.270,000 people and a land area of 5,400ha (c.208 square miles). It was constructed in 2011 and comprises three storeys, with a gross floor area (GFA) of 10,300m² of office space arranged predominantly in an open floor design, surrounding a central atrium. The main entrance is located at ground floor level (Figure 1).

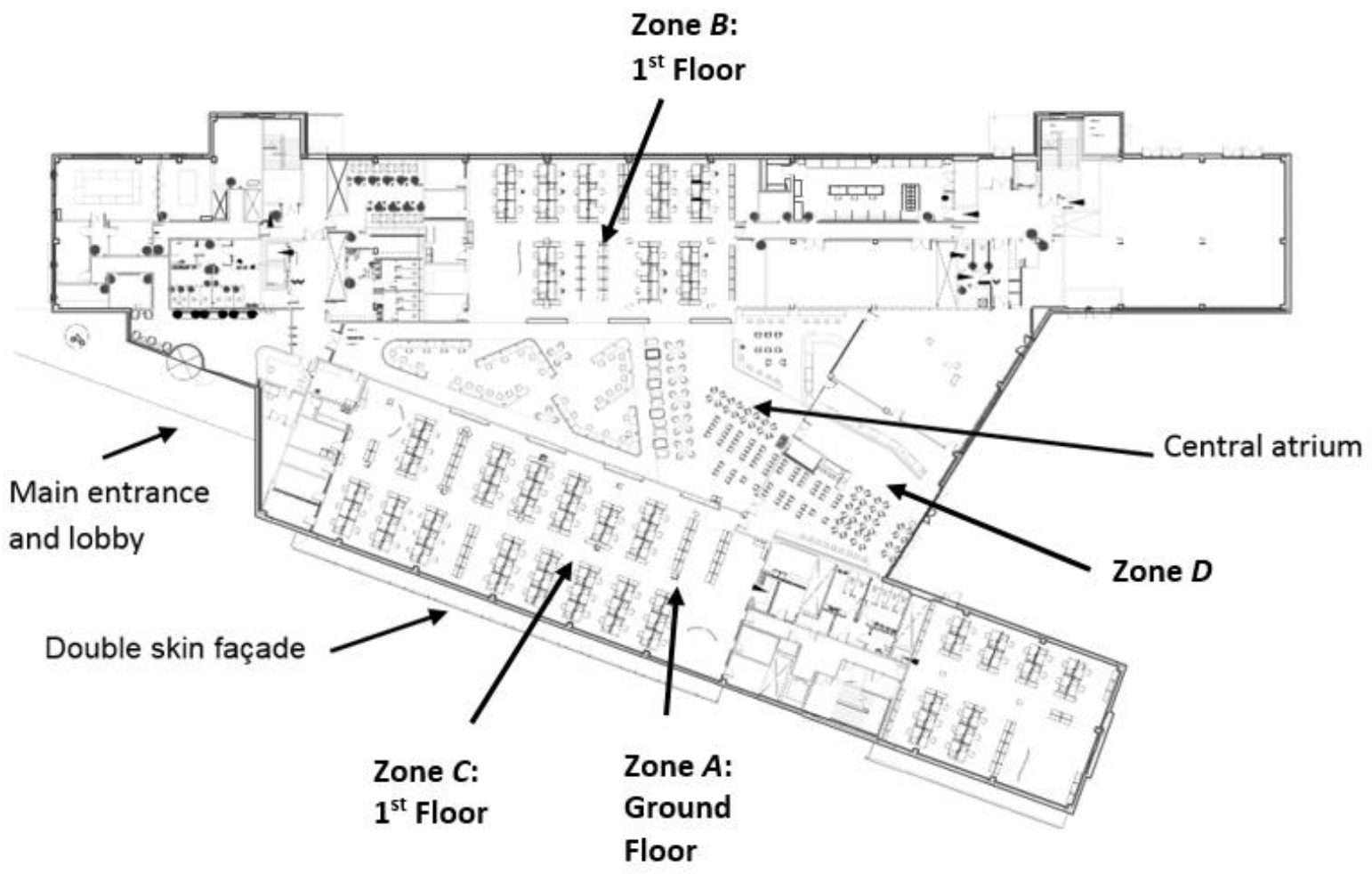

Figure 1. Plan design schematic for the ground floor

The building has an energy performance operational rating of ' $\mathrm{C}$ ' (Department for Communities and Local Government, 2015) with an annual gas and electricity consumption of 73 and $72 \mathrm{kWh} / \mathrm{m}^{2} \mathrm{GFA} /$ annum respectively. Approximately, $13 \%$ of the former and $0.4 \%$ of the latter is sourced from renewable energy. Gas is the main heating fuel, while electricity is 
used for lighting and all other power requirements typical of an office building. Building services are fully linked to a central Building Management System, which controls lighting, ventilation, heating, and the opening and closing of apertures. The building design allows a high percentage of ventilation to be achieved via natural 'stack effect' through the atrium. Strategically located $\mathrm{CO}_{2}$ sensors monitor IAQ with the mean indoor $\mathrm{CO}_{2}$ concentration maintained at circa $850 \mathrm{ppm}$. For this study, supplemental $\mathrm{CO}_{2}$ readings were recorded with a handheld Solomat MP Surveyor PRO, Zwellweger Analytics $\mathrm{CO}_{2}$ sensor. Similarly, indoor lighting and noise levels were recorded with a handheld PeakTech 5035 sensor. These sensors were calibrated by their respective suppliers prior to the commencement of the study.

A central HVAC system, located on the rooftop, provides heating and supplemental ventilation through floor level diffusers with winter and summer indoor point temperatures set at $22^{\circ} \mathrm{C}$. No cooling or humidification systems are available. Figure 2 shows the central atrium and double skin south facing façade. The façade offers sound insulation from a high-volume traffic road parallel to it, as well as shading, to minimise solar gains during peak summer months. At the time of the study there were circa 1,000 adults working in the building, typically between the hours of 8am and 7pm. As illustrated in Figure 1, a single experimental zone (Zone A) and two control zones (Zones B\&C) were designated. The number of employees and moisture buffering from surface finishes and furniture in each zone was assumed to be identical. Moreover, with the staff canteen and toilets (Zone D) abutting on the atrium, the exposure of each zone to moisture originating from these locations was assumed to be equal. 


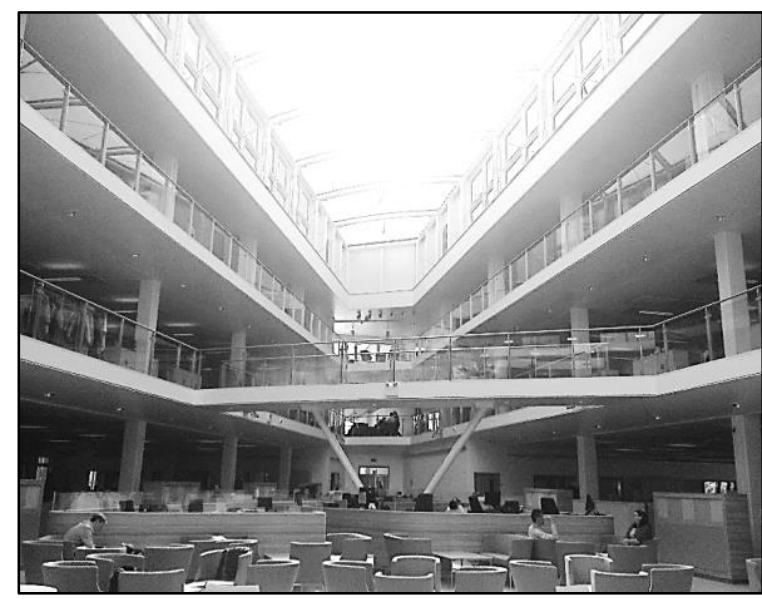

2 (a) Atrium design

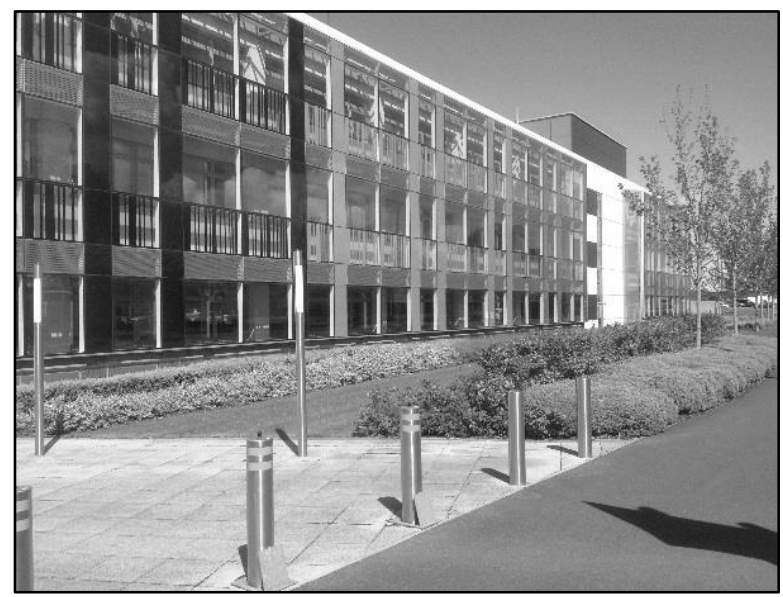

2 (b) South facing façade
253

254

255

256

257

258

259

\section{Figure 2. The office building}

\subsection{Theoretical calculations of mechanical humidification}

The water vapour per unit volume of dry air required for the elevation of the indoor $\% R H$ to the lower recommended limit of $40 \% R H$, was calculated using a psychrometric chart, based on measured indoor air temperature and $\% R H$ readings. Subsequently, the total mass of water vapour per unit time $(\mathrm{kg} / \mathrm{hr})$, required as a function of the building occupants and the mean fresh air ventilation rate, was derived from:

$$
\dot{m}_{m}=m\left(3.6 \rho_{a i r} n v_{f a}\right)
$$

where: $m$ is the mass of water vapour per $\mathrm{kg}$ of dry air; $\rho_{\text {air }}$ is density of air $\left(\mathrm{kg} / \mathrm{m}^{3}\right) ; n$ is the number of employees; $v_{f a}$ is the fresh air volume flow rate (L/s) (CIBSE, 2005). A fresh air ventilation rate of $8 \mathrm{~L} / \mathrm{s}$ was assumed, which would yield an indoor $\mathrm{CO}_{2}$ concentration of circa $1,000 \mathrm{ppm}$ (CIBSE, 2006). The heating power required to heat fresh water from an assumed $20^{\circ} \mathrm{C}$ to boiling point, was calculated using: 
272 where: $Q_{w}$ is the heating power (W); $\dot{m}_{m}$ is the mass of water required per hour calculated from 273 equation (1); $C_{p}$ is the specific heat capacity of water $(\mathrm{J} / \mathrm{kgK})$; and $\Delta T$ is the change in water 274 temperature (i.e. from $20^{\circ} \mathrm{C}$ to $100^{\circ} \mathrm{C}$ ). The heating power required to evaporate water at $1 \mathrm{Bar}$ 275 was calculated from:

276

277

$Q_{s t}=\dot{m}_{m} \Delta H_{v a p}$

278

279

where: $\Delta H_{\text {vap }}$ is the enthalpy of vapourisation $(\mathrm{kJ} / \mathrm{kg})$. Hence, the total power $\left(Q_{t o t}\right)$ required 280 for the production of steam was calculated from addition of equations (2) and (3). That is:

281

282

$Q_{t o t}=Q_{w}+Q_{s t}$

283

284

Using a mean daily operating time of 11 hours, the energy required for production of steam per 285 month was derived from:

286

287

$E=\frac{Q_{t o t} t}{1000}$

288

289

where: $E$ is the energy consumed $(\mathrm{kWh})$ and $t$ is time (hrs). The predicted energy saving per month as a result of water vapour contribution from the indoor plants, was calculated from:

291

$292 \quad E_{\text {sav }}=\left[\frac{\dot{m}_{p l}}{\dot{m}_{m}}\right] E$ 
where $\dot{m}_{p l}$ is the mass of water vapour transpired by the plants per unit time $(\mathrm{kg} / \mathrm{hr})$.

Hence, equation (6) was used to quantify the tangible benefits of using indoor plants to supplement the indoor $R H$. As discussed later, these gains take the form of financial savings and environmental benefits, as a result of reduced gas consumption.

\subsection{Planting arrangements}

Live indoor plants were installed in the building among the first floor southern section of the building (refer Figure 1) for a period of 6 months. These areas were chosen because they are of similar size and are occupied by approximately the same number of people, doing similar jobs (Smith et al., 2011). The plants were selected mainly for their transpiration rates according to Wolverton (1996) as well as factors such as: ease of maintenance, light requirements, size, shape and general aesthetic qualities (Smith et al., 2011). This was all in accordance with the advice of a professional indoor planting company, who also supplied and carefully maintained the plants throughout the trial period. Maintenance is important because plants must be in optimal condition, for them to be successful in regulating indoor climate (Costa and James, 1995; Smith and Pitt, 2011) - this included watering (volumes recorded), dusting, and pest control (using natural products) every 2 weeks.

The plants are detailed in Table 1 . They were installed at a density of one plant per $10 \mathrm{~m}^{2}$, a density slightly higher than under 'normal' commercial conditions. They included 30 floorstanding varieties and a range of 24 smaller desk bowls, mainly positioned on shared furniture, such as filing cabinets. The plants were all soil-grown and without top dressing. In line with the planting company's advice, the total transpiration for the experimental zone was calculated to be approximately 21 litres of water per 24 hours. 
[Insert Table 1 here].

321

Table 1. Plant species installed in the experimental zone

323

324

\subsection{Relative humidity}

325

Two newly calibrated column-mounted HOBO UX100-003 humidity sensors (accuracy +/$3.5 \%$ ) were mounted in each zone (six sensors in total); at a height of circa $1.6 \mathrm{~m}$ above floor level on support columns located in the central part of the monitored zones. Their readings were automatically logged at half-hourly intervals and resulting ratios of actual water vapour density to the saturation vapour density were calculated from:

330

331

$\% R H=\frac{\rho_{\text {actual }}}{\rho_{\text {saturation }}}$

Figure 3 shows that saturation vapour density is directly related to air temperature, such that a unit increase in air temperature results in an exponential rise in its ability to hold water vapour. Hence, if supplemental water vapour is not added to heated indoor air, its $\% R H$ decreases appreciably. Testing for VOCs used ISO 16000-4-2004 standard formaldehyde and Total VOC testing kits. Two samples were logged for each of the three zones, with the first sample taken during February and the final sample taken during June. 


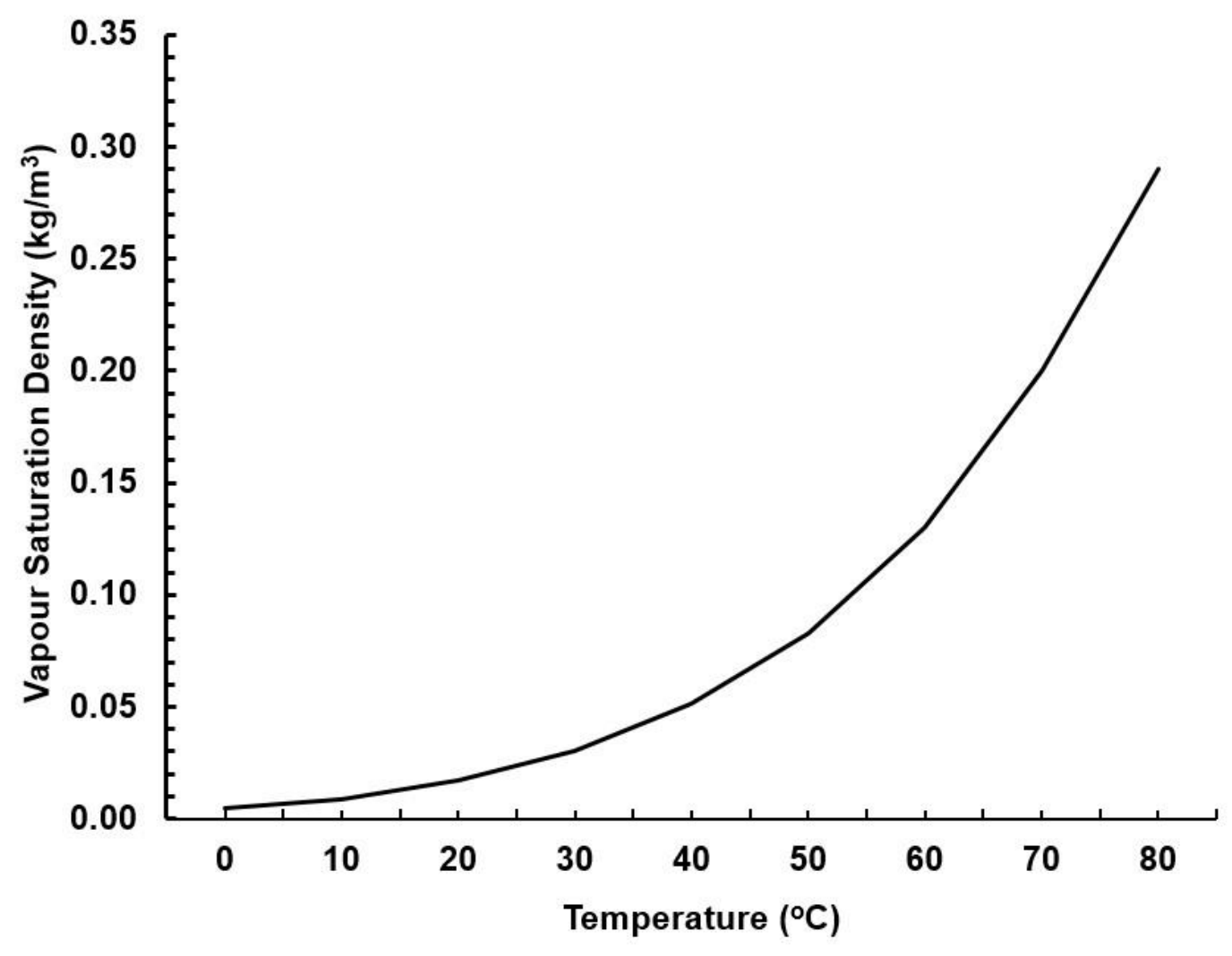

Figure 3. Vapour saturation density with temperature

342

The water vapour volume that evaporated from the 54 indoor plants was calculated from:

344

345

$\dot{m}_{p l}=T R\left(n_{p l} A\right)$

346

347 where: $T R$ is the mean transpiration rate of $0.0218 \mathrm{~kg} / \mathrm{hr} / \mathrm{m}^{2}$ (Hussarang et al., 2011); $n_{p l}$ is the number of plants; and $A$ is a mean foliage area of $0.906 \mathrm{~m}^{2}$ per plant (ibid.). By way of checking, the total water vapour volume mass produced, was compared to that of water supplied to the plants over the duration of the project. The outcome was validated with the supply value being $+/-10 \%$ of $\dot{m}_{p l}$.

352

353

3.5 Employee perceptions 
During the last two weeks of the trial period (June 2015), employees' perceptions of their

working environment were sampled among both the 'trial' and 'control' zones, using an online questionnaire. This method was chosen for ease of distribution (Heiervang and Goodman, 2009); efficiency (Hardigan et al., 2012); and convenient data export (Archer, 2003). It also encouraged employees, to complete the survey via their desk terminal while within the survey (work) environment. The questionnaire asked employees to consider whether any of four environmental aspects had 'improved', 'stayed the same', or 'got worse' since the plant trial had commenced. These aspects were: humidity; temperature; background noise levels; and environment aesthetics.

Among the control zones there were $61(55 \%)$ respondents. The remainder ( $n=49$, or $45 \%)$ of the sample were from the trial zone. The total 110 respondents formed a reliable sample given their proportion of the original population, and because where $n>30$ normality can be tentatively assumed - even more so, as $n$ increases thereafter (Mordkoff, 2011). Data were analysed using real numbers and percentages, to create graphical categorical comparisons methods appropriate for interpretation of results among nominal or interval data (Holt, 2014).

\section{Results and discussion}

Figure 4 shows the $\% R H$ and indoor temperatures during a week in February (a) and another in June (b). In contrast to expectations, the $\% R H$ in the experimental zone was quasi-identical to those in the control zones. Moreover, the data suggest that the $\% R H$ (in all zones) is highest during the late morning/early afternoon, which may be attributed to the peak number of employees in the building at about this time. 
Figure 5 presents the average measured external temperature, internal temperatures and $\% R H$

379 (combined for all zones) over the trial period. In agreement with concerns reported by the

380 building's facilities management, indoor $\% R H$ during the months of January to April was

381 below the recommended CIBSE minimum of 40\% (CIBSE, 2005; Wan et al., 2009). The

382 lowest indoor $R H$ levels were recorded during February while the highest levels were recorded

383 during late spring months. These results can be directly associated with corresponding outdoor

384 temperatures. For example, during February outside cold air contained much less water vapour

385 at saturation conditions, so the heating of this air to room temperature yielded a significant drop

386 in indoor $R H$.

387

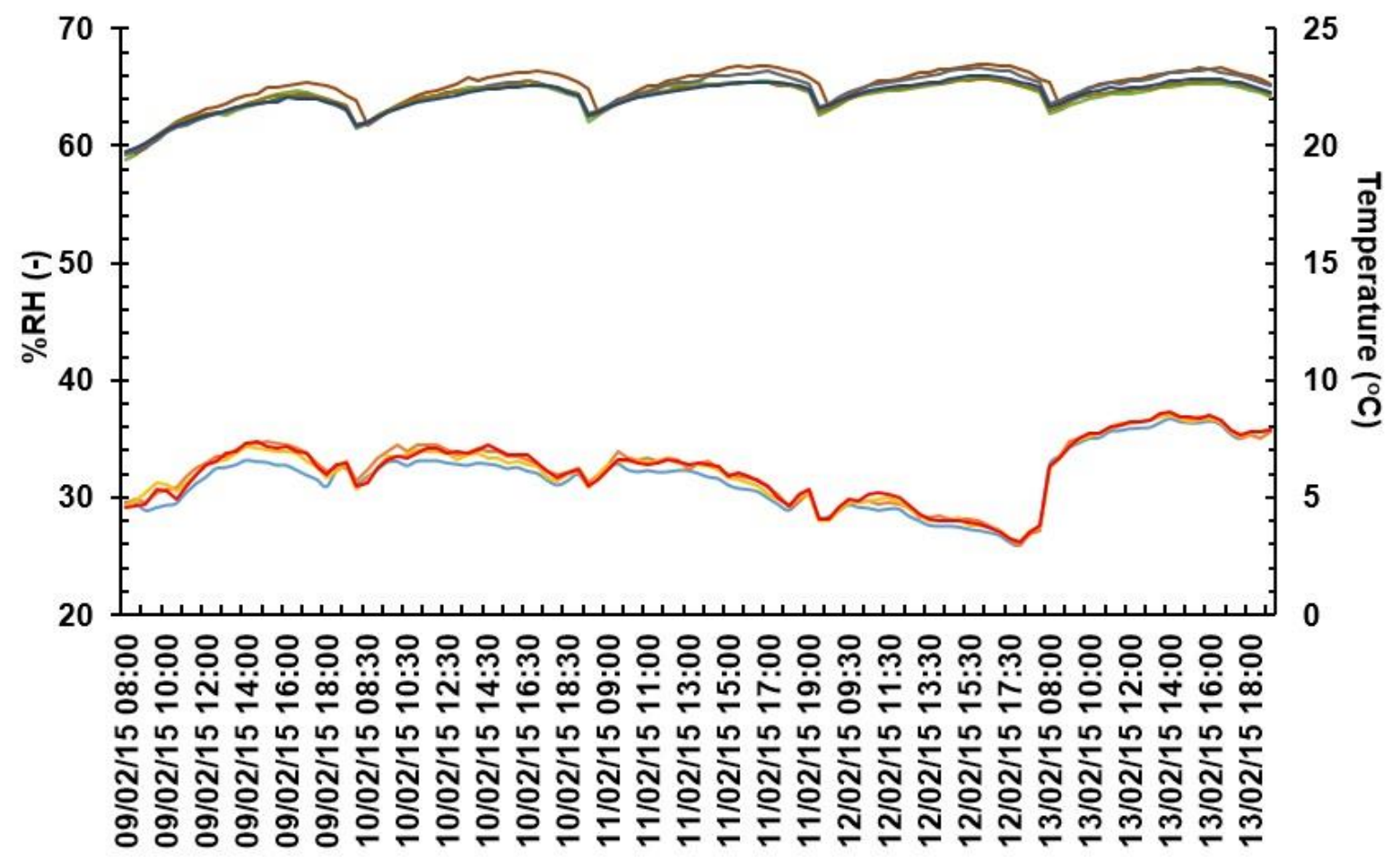




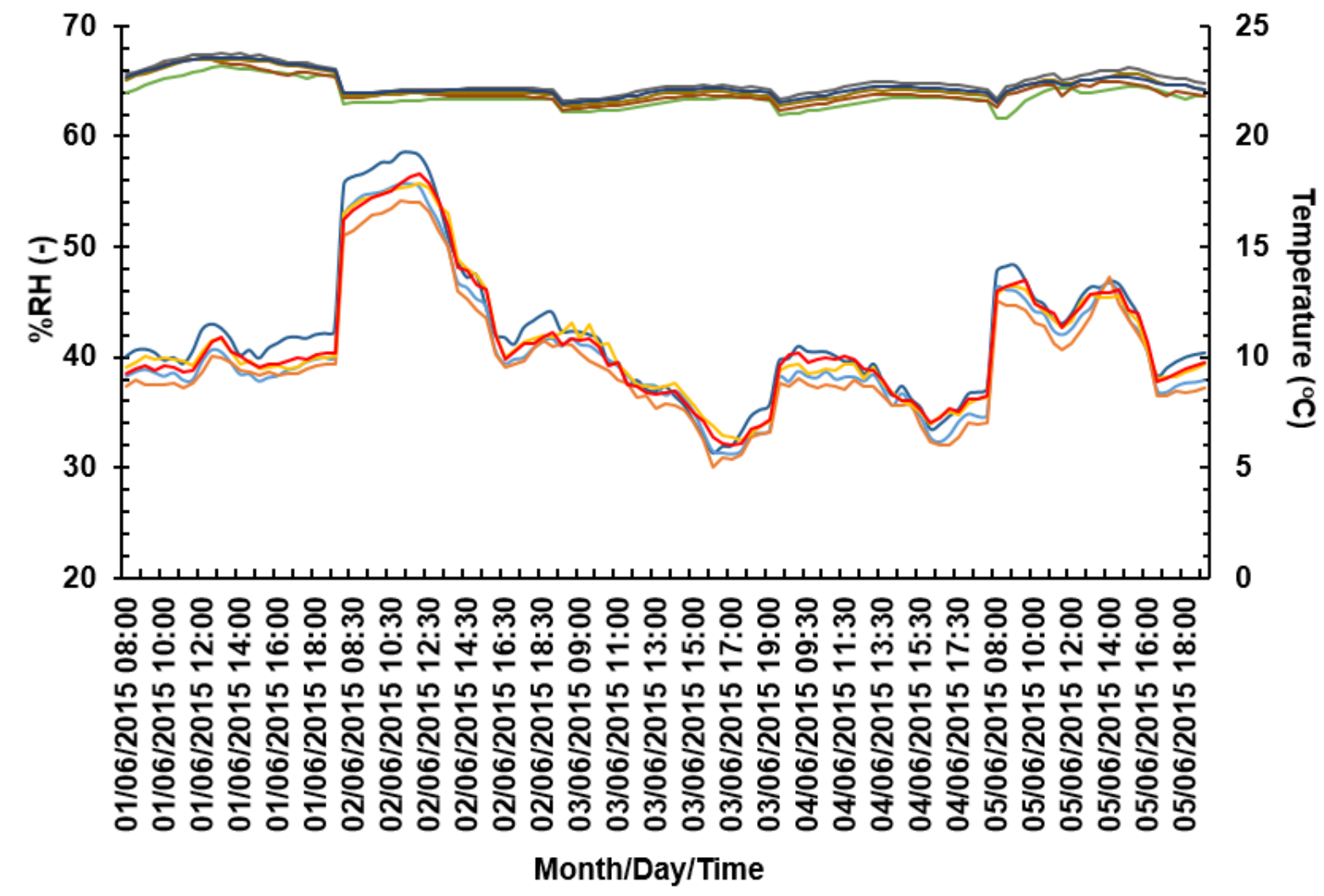

4 (b) June

\begin{tabular}{|l|}
\hline -Ground Floor - Control sensor 1 - Zone A (\%RH) \\
- Ground Floor - Control sensor 2 - Zone A (\%RH) \\
1st Floor Control - Control sensor 3 - Zone B (\%RH) \\
1st Floor Experimental - Sensor 5 - Zone C (\%RH) \\
1st Floor Experimental - Sensor 6 - Zone C (\%RH) \\
-Ground Floor - Control sensor 1 - Zone A (Temp) \\
- Ground Floor - Control sensor 2 - Zone A (Temp) \\
1st Floor Control - Control sensor 3 - Zone B (Temp) \\
-1st Floor Experimental - Sensor 5 - Zone C (Temp) \\
\hline 1st Floor Experimental - Sensor 6 - Zone C (Temp)
\end{tabular}

Figure 4. \%RH and indoor temperature with time (office hours) during a week in

February (a) and June (b) 


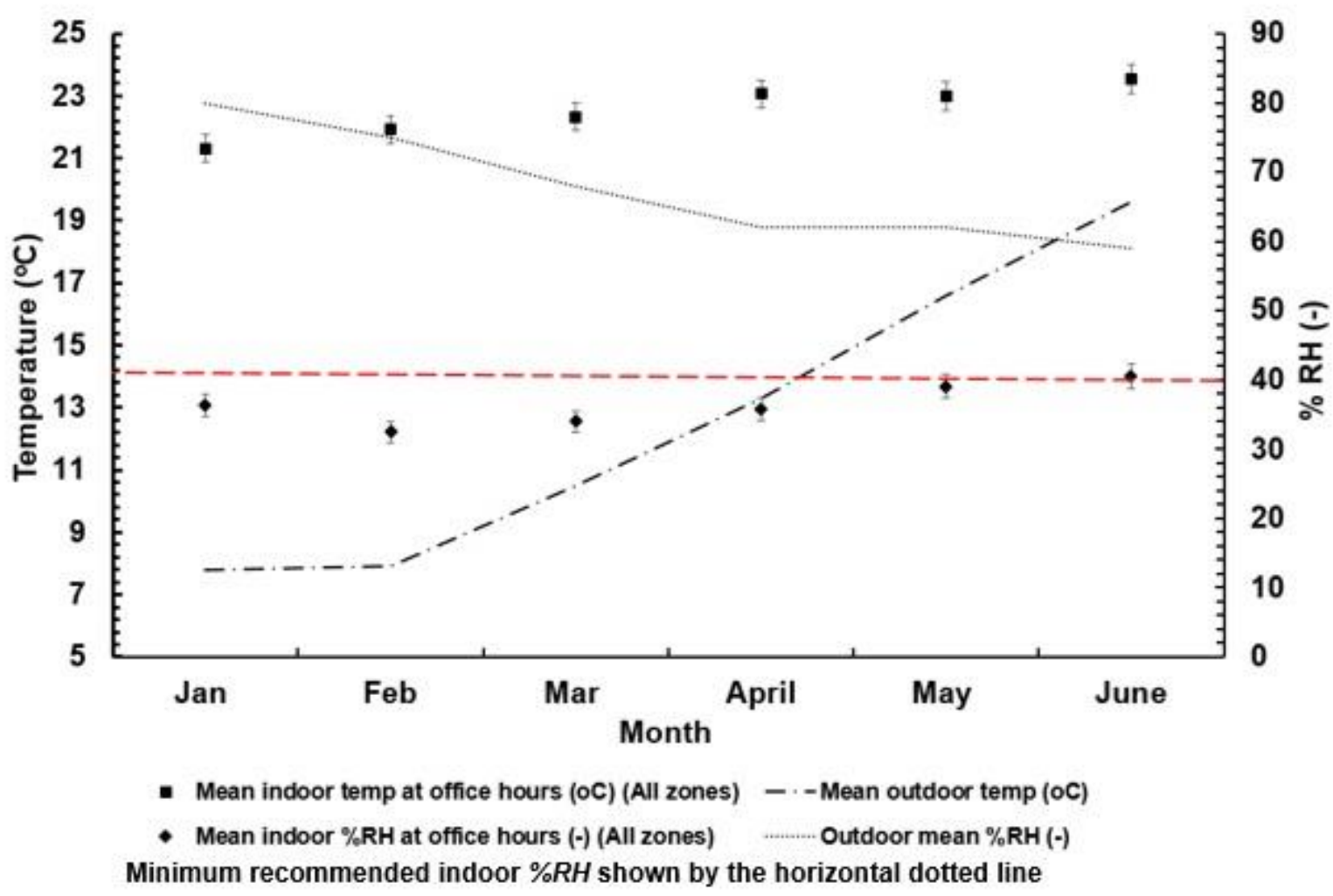

Figure 5. Average measured indoor temperatures, outdoor temperatures and \%RH

Indoor $\% R H$ values for the experimental and control zones were quasi-identical, and so are grouped together in Figure 5. These findings contrast a-priori expectations - given that a total volume of 3,822 litres of water were supplied to the plants during the six month trial period. Moreover, with a total foliage area of circa $49 \mathrm{~m}^{2}$, a mean transpiration rate of circa $18 \mathrm{~g} / \mathrm{hr} / \mathrm{m}^{2}$ was calculated [in reasonable agreement with the transpiration rate of $21.8 \mathrm{~g} / \mathrm{hr} / \mathrm{m}^{2}$ reported by Hassarang et al. (2011)]. Figure 6 shows how these transpiration rates were expected to significantly reduce mechanical humidification energy demands. For a sustained indoor $40 \% R H$, mechanical humidification with no indoor plants, was calculated to increase gas consumption by $7 \%$. Hence, during January and February, the plants were predicted to reduce mechanical humidification energy by 75 and 38 per cent respectively (a saving of circa 6,000 $\mathrm{kWh}$ over the period). For the trial period, a total $\mathrm{CO}_{2}$ reduction of 2,200kg (Figure 7) was 411 calculated (Department for Environment Food and Rural Affairs, 2015). 


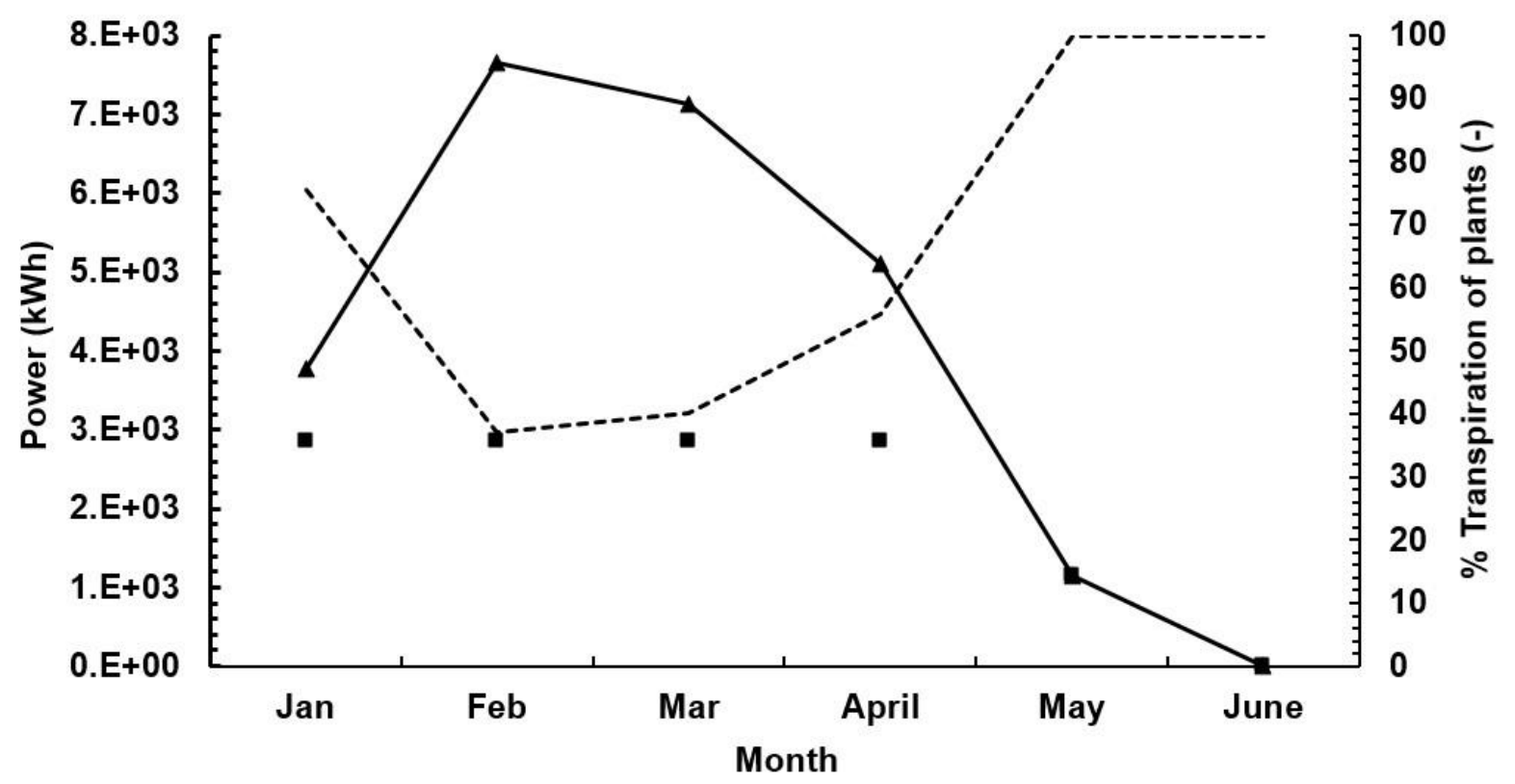

- Power required for the humidification of the supply air with direct steam injection

- Humidification power savings with a vapour supplement from indoor plants

----Transpiration of plants as a percentage of the vapour top-up required for a sustained indoor $\%$ RH of 40

414 Figure 6. Theoretical power consumption with indoor air-humidification provision and

415 potential power savings with a vapour supplement from indoor plants

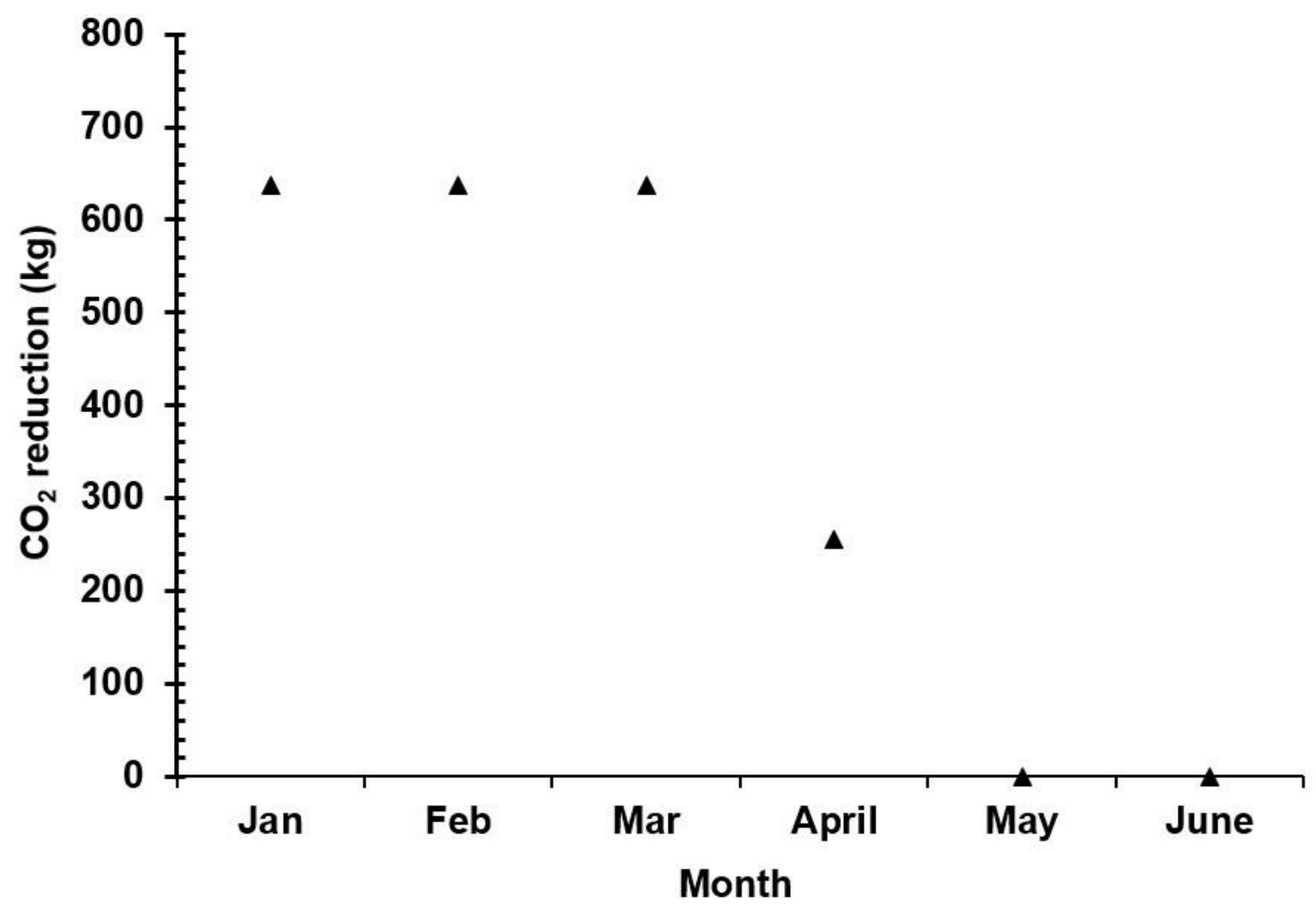




\section{Figure 7. Theoretical $\mathrm{CO} 2$ gas reduction with indoor plants}

The marked differences between measured and predicted $\% R H$ may be attributed to building 420 design, which it is assumed, allowed cross-contamination of indoor air between the experimental and control zones. It is logical to infer that this resulted in some dilution of the concentration of water vapour, transpired by the plants located in the experimental zone. A corollary of this suggests it will be necessary to populate all of the building's indoor areas with

424 plants, to achieve enhanced indoor humidity levels. Moreover, indoor $\mathrm{CO}_{2}$ gas concentration 425 data suggest that results were not attributable to over-ventilation. Recorded mean indoor $\mathrm{CO}_{2}$ concentration was in the range of $850-1000 \mathrm{ppm}$, this being indicative of good IAQ (Usha et al., 2012). This suggests an approximate ventilation rate of 8-10 L/s per person (CIBSE, 2006).

Figure 8 shows the measured concentrations for TOTAL VOCs (TVOCs) and formaldehyde, at $\mu \mathrm{g} / \mathrm{m}^{3}$ among the control and experimental areas. Both sets of data show concentrations much lower than the recommended maximum of 100 and $300 \mu \mathrm{g} / \mathrm{m}^{3}$ for formaldehyde and TVOCs respectively (World Health Organisation, 2010). This additionally suggests no substantial differences in the concentrations of experimental vis-à-vis control zones. However,

434 it is evident that during June, the TVOC concentrations were consistently lower than during 435 January. Given that formaldehyde concentration and $\mathrm{CO}_{2}$ readings were consistent for both months, these results do not appear due to higher ventilation rates, and so remain indeterminate. 


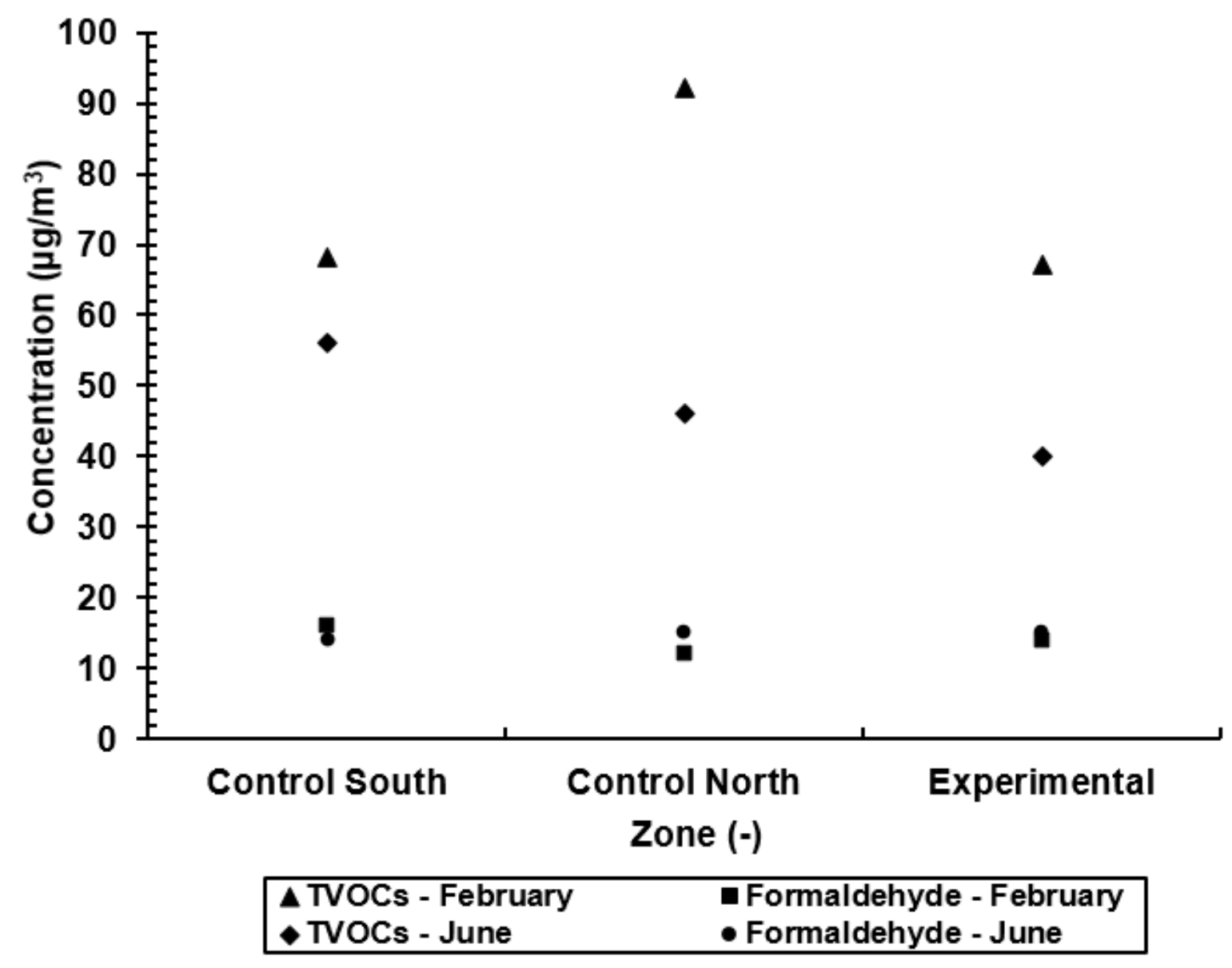

Figure 8. VOC measurements for the experimental and control zones

441 The questionnaire survey found a noticeable shift in perceptions within the experimental zone; approximately one-quarter of respondents felt that indoor $R H$ had improved. This contradicts actual $R H$ measurements and so suggests a misperception. While beyond the remit of this study, reasons for misperception include distortion from an array of cognitive, perceptual and motivational biases [reasoning error; experientially influenced perception; and personal or 446 situational leanings, respectively (Pronin, 2007)]. In this instance, maybe from optimism bias, 447 which is the tendency to underestimate the likelihood of being affected by adverse events or conditions (Moss, 2016); or acquiescence bias, which is the tendency to respond affirmatively to survey items irrespective of substantive content (Watson, 1992). Notably, almost all respondents from the control groups felt that $R H$ had not changed. Figure 9(a) shows all results 
between both groups in terms of $R H$ perceptions. A similar condition was reported regarding

452

453

454

455

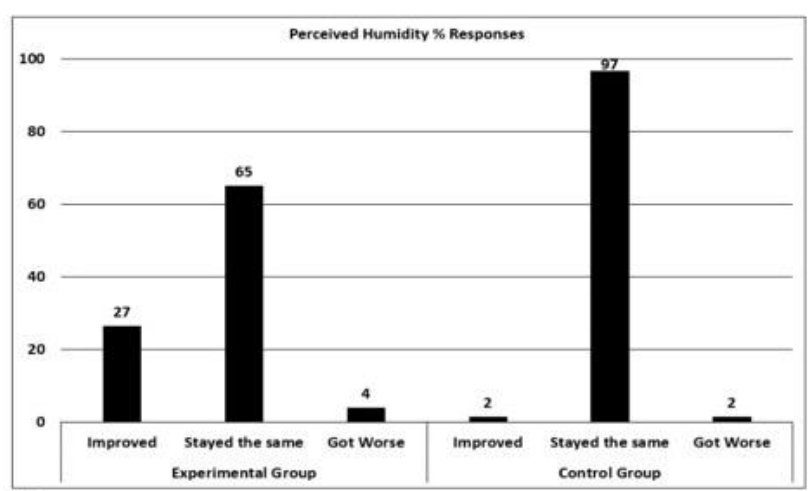

(a) Humidity perceptions

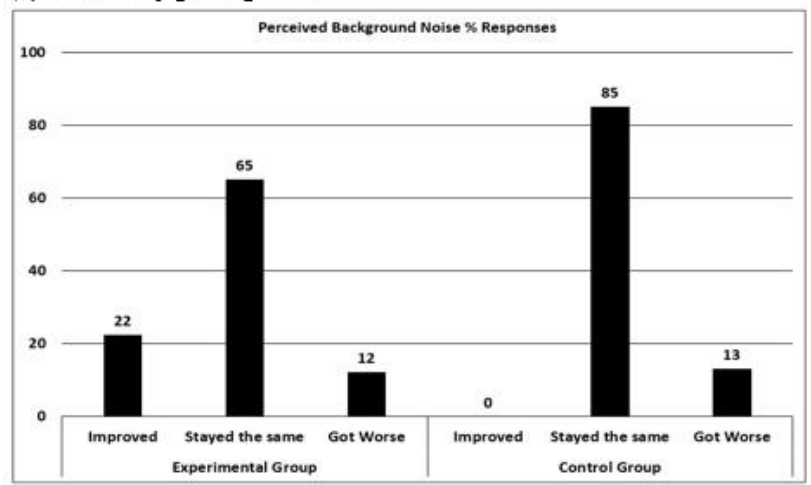

(c) Background noise perceptions

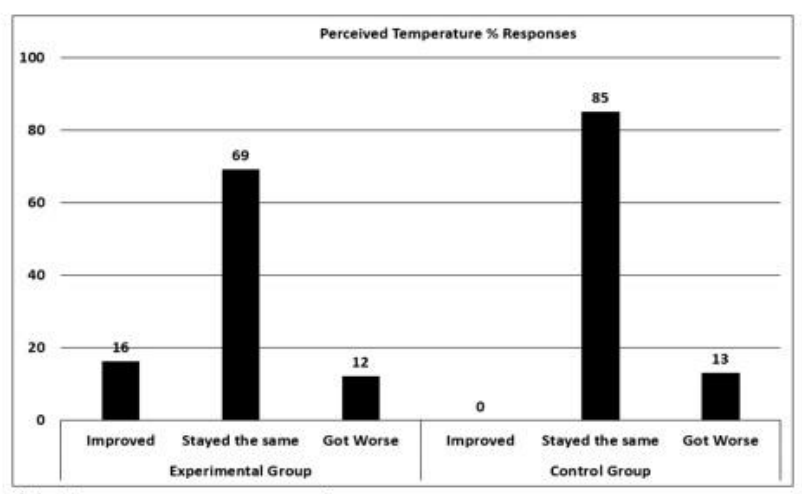

(b) Temperature perceptions

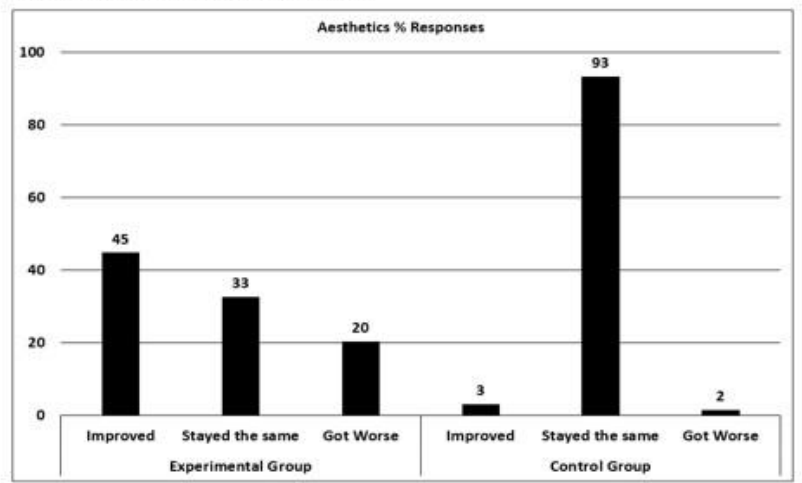

(d) Aesthetic perceptions

Figure 9. Results of the questionnaire survey

In accordance with research by Costa and James (1995) and Freeman (2008), the questionnaire

results suggest a perceived improvement in background noise levels, within the experimental area. Although this contradicts physical measurements (mean noise levels of $45-55 \mathrm{~dB}$ were measured among all zones), it may provide an indication of the sound absorption properties of plants in buildings (or a reduction in reverberation times that was perceived as reduction in noise). Twenty-two per cent of experimental area respondents reported this improvement, compared to none in the control areas (Figure 9(c)). 
467 The most marked perceived improvement was for aesthetics within the experimental area. 468 Figure 9(d) shows that almost half of respondents reported this, although one-fifth of 469 experimental area respondents suggested that aesthetics got worse. This reflects the subjective 470 nature of office design considerations and individuals' differing opinions as to the addition of 471 indoor plants at work. Nonetheless, these results concur with Smith and Pitt (2008) who found a general preference for plants in this context.

\section{5. Conclusions}

475 The study has presented a mix of numerical and qualitative investigations regarding the impact of living plants on IAQ. The measured indoor $R H$ suggests that despite what theoretical calculations predicted, in practice the humidification effect of the plants was not discernible. The research team feel that this is mainly due to the open plan design of the building, which allowed cross-contamination of air between those zones studied. The volume of water supplied to the plants over the investigation period, together with calculations of their typical transpiration rates based on the literature, suggests that during winter months, indoor plants offer the potential to reduce mechanical humidification power requirements by up to $75 \%$. These savings were calculated based on a minimum indoor $R H$ of $40 \%$ (a comfortable and healthy indoor environment for the building's occupants).

Changes in perception were shown to contrast those physical data measured in relation to indoor $R H$, temperature, and background noise levels. This misperception probably results from optimism or acquiescence bias, and suggests that future perception surveys of indoor planting need to account for this, in questionnaire design. The most marked improvement 
related to aesthetics in the experimental zone where the plants were located, supporting an argument that office occupants appreciate the presence of natural elements such as plants.

This research suggests that analysis of airflow patterns within the building using computational fluid dynamics would be beneficial, in order to study the degree to which inter-zone mixing of air can affect positive $R H$ gains from indoor planting. Linked to this, future work will also assess the effect of indoor planting throughout all of the building. This in addition, will further knowledge of zonal air interfaces in the present context; and equally compare occupants' perceptions of those indoor environmental criteria used in the present study.

\section{References}

Archer, T.M. (2003), “Web-based Surveys”, Journal of Extension, Vol. 41 No. 4. Available at: http://www.joe.org/joe/2003august/tt6.php (accessed 23 April 2016).

Baur, X., Bakehe, P., Vellguth, H. (2012), "Bronchial Asthma and COPD due to irritants in the workplace: an evidence-based approach", Journal of Occupational Medicine and Toxicology, Vol. 7, No. 19, p. 19.

Bringslimark, T., Hartig, T., Patil, G. (2011), “Adaptation to windowlessness: Do office workers compensate for a lack of visual access to the outdoors?", Environment and Behavior, Vol. 43, No. 1, pp. 469-487.

Bron A.J., Tiffany J.M., Gouveia S.M., Yokoi N., Voon L.W. (2004), "Functional aspects of the tear film lipid layer", Experimental Eye Research, Vol. 78, No. 3, pp. 347-360.

Cackowski, J.M., Nasar, J.L. (2003), "The restorative effects of roadside vegetation: Implications for automobile driver anger and frustration", Environment and Behavior, Vol. 35, No. 6, pp. 736-751.

Chao, C.Y.H. (2001), "Comparison between indoor and outdoor air contaminant levels in residential buildings from passive sampler study”, Building and Environment, Vol. 36, pp. 999-1007.

Chartered Institution of Building Services Engineers (CIBSE) (2005), Heating, ventilation, airconditioning and refrigeration - CIBSE Guide B, 7 th Edition, $I^{\text {st }}$ Edition, CIBSE Publications, Norwich, United Kingdom.

Chartered Institution of Building Services Engineers (CIBSE) (2006), Environmental design - CIBSE Guide A, $7^{\text {th }}$ Edition, CIBSE Publications, Norwich, United Kingdom.

Costa, P., James, R.W. (1995), "Constructive use of vegetation in office buildings", paper presented at Plants for People Symposium, 23 November, The Hague, Netherlands, available at: http://www.healthygreenatwork.org/index en.cfm?act=artikelen.details\&varart=18 (accessed 15 May 2016). 
Doty R.L., Cometto-Muniz J.E., Jalowayski A.A., Dalton P., Kendall-Reed M., Hodgson M. (2004), "Assessment of upper respiratory tract and ocular irritative effects of volatile chemical in humans", Critical Review Toxicology, Vol. 34, No. 2, pp. 85-142.

Department for Environment Food and Rural Affairs (2015), "UK Government Carbon conversion factors for government reporting", available at: http://www.ukconversionfactorscarbonsmart.co.uk (accessed 15 May 2016).

Department for Communities and Local Government (2015), "Display energy certificates and advisory reports for public buildings" available at: https://www.gov.uk/government/publications/display-energy-certificates-and-advisoryreports-for-public-buildings (accessed 15 May 2016).

Ekberg L.E., (1994), "Volatile organic compounds in office buildings", Atmospheric Environment, Vol. 28, No. 22, pp. 3571-3575.

Freeman, K. (2008), "Plants in Green Buildings", Unpublished Manuscript, Ambius White Paper 01, Ambius University, Buffalo Grove, USA.

Giese, M., Bauer-Doranth, U., Langebartels, C., Sandermann Jr., H. (1994), "Detoxification of formaldehyde by the spiderplant (Chlorophytum comosum L.) and by soybean (Glycine max L.) cell-suspension cultures", Plant Physiology, Vol. 104, No. 4, pp. 1301-1309.

Godish, T., Guindon, C. (1989), "An assessment of botanical air purification as a formaldehyde mitigation measure under dynamic laboratory chamber conditions", Environmental Pollution, Vol. 62, No. 1, pp. 13-20.

Gou, Z., Lau, S. (2012), "Sick building syndrome in open-plan offices: Workplace design elements and perceived indoor environmental quality", Journal of Facilities Management, Vol. 10, No. 4, pp. 256-265.

Hardigan P.C., Succar, C.T. and Fleisher, J.M. (2012), “An Analysis of Response Rate and Economic Costs between Mail and Web-Based Surveys among Practicing Dentists: A Randomized Trial”, Journal of Community Health, Vol. 37, No. 2, pp. 383-394.

Heiervang, E., Goodman, R. (2009), "Advantages and Limitations of Web-based Surveys: Evidence from a Child Mental Health Survey”, Social Psychiatry and Psychiatric Epidemiology, Vol. 46, No. 1, pp. 69-76.

Hetreed, J. (2008). The Damp House: A Guide to the Causes and Treatment of Dampness. Wiltshire: The Crowood Press Ltd.

Holt, G. D. (2014), Guest Editorial - “Asking Questions, Analysing Answers: Relative Importance Revisited”, Construction Innovation: Information, Process, Management, Vol. 14, No. 1, pp. 2-16.

Hussarang O., Boonkorkaew P., Kasemsap P. (2011), "Study on transpiration of indoor decorative plants", in Proceedings of the $49^{\text {th }}$ Kasetsart University Annual Conference, Kasetsart University, Thailand, 1-4 February 2011, Vol. 1, pp. 272-281.

Irga, P.J., Torpy, F.R., Burchett, M.D. (2013), "Can hydroculture be used to enhance the performance of indoor plants for the removal of air pollutants?", Atmospheric Environment, Vol. 77, pp. 267-271.

Kaplan, R. (1993), "The role of nature in the context of the workplace", Landscape and Urban Planning, Vol. 26, Nos. 1-4, pp. 193-201.

Kuo, F.E., Sullivan, W.C. (2001), "Environment and crime in the inner city: Does vegetation reduce crime?", Environment and Behaviour, Vol. 33, No. 3, pp. 343-367.

Latif, M.T., Baharudin, N.H., Velayutham, P., Awang, N., Hamdan, H., Mohamad, R., Mokhtar, M.B. (2011) "Composition of heavy metals and airborne fibers in the indoor environment of a building during renovation”, Environmental Monitoring and Assessment, Vol. 181, No. 1-4, pp. 479-490. 
Lee S.C., Li W., Ao C.H. (2002) "Investigation of indoor air quality at residential homes in Hong Kong - A case study”, Atmospheric Environment, Vol. 36, No. 2, pp. 225-237.

Lee, M., Lee, J., Park, B., Miyazaki, Y. (2015), “Interaction with indoor plants may reduce psychological and physiological stress by suppressing autonomic nervous system activity in young adults: a randomized crossover study", Journal of Physiological Anthropology, Vol. 34, pp. 21-26.

Leather, P., Pyrgas, M., Beale, D., Lawrence, C. (1998), "Windows in the workplace: Sunlight, view and occupational stress", Environment and Behaviour, Vol. 30, No. 6, pp. 739-762.

Lohr, V.I., Pearson-Mims, C.H., Goodwin, G.K. (1996), "Interior plants may improve worker productivity and reduce stress in a windowless environment", Journal of Environmental Horticulture, Vol. 14, No. 2, pp. 97-100.

Lutz, A.R., Simpson-Housley, P., De Man, A.F. (1999), "Wilderness: Rural and urban attitudes and perceptions", Environment and Behaviour, Vol. 31, No. 2, pp. 259 - 266.

Meininghaus, R., Kouniali, A., Mandin, C., Cicolella, A. (2003), "Risk assessment of sensory irritants in indoor air - a case study in a French school”, Environment International, Vol. 28, No. 7, pp. 553-557.

Mordkoff, J.T. (2011), "The Assumption(s) of Normality”, available at: http://www2.psychology.uiowa.edu/faculty/mordkoff/GradStats/part\%201/I.07\%20normal.p

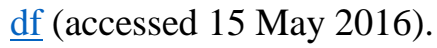

Moss, S. (2016), “Optimism bias”, available at: http://www.sicotests.com/psyarticle.asp?id=238 (accessed 12 December 2016).

Nagda N.L., Hodgson M.H. (2001), "Low relative humidity and aircraft cabin air quality", Indoor Air, Vol. 11, No. 3, pp. 200-214.

Oyabu, T., Sawada, A., Onodera, T., Takenaka, K., Wolverton, B. (2003), "Characteristics of potted plants for removing offensive odors", Sensors and Actuators B, Vol. 89, Nos. 1-2, pp. 131136.

Oxley, T.A. and Gobert, E.G. (2011). Dampness in Buildings. Diagnosis, Treatment and Instruments. Abingdon, Oxon: Spon Press.

Pronin, E. (2007), "Perception and misperception of bias in human judgment", Trends in Cognitive Sciences, Vol.11, No.1, pp. 37-43.

Reynolds, S., Kreiger, R., Bohn, J., Fish, D. (1994) "Factors affecting airborne concentrations of asbestos in a commercial building", American Industrial Hygiene Association Journal, Vol. 55, No. 9, pp. 823-828.

Rios, J., Boechat, J., Gioda, A., Santos, C., Neto, F., Silva, J. (2009) "Symptoms prevalence among office workers of a sealed versus a non-sealed building: Associations to indoor air quality", Environment International, Vol. 35, No. 8, pp. 1136-1141.

Salonen, H., Pasanen, A-L., Lappalainen, S., Riuttala, H., Tuomi, T., Pasanen, P., Back, B., Reijula, K. (2009), "Volatile Organic Compounds and Formaldehyde as explaining factors for sensory irritation in office environments", Journal of Occupational and Environmental Hygiene, Vol. 6, No. 4, pp. 239-247.

Sheets, V.L., Manzer, C.D. (1991), “Affect, cognition and urban vegetation: Some effects of adding trees along city streets", Environment and Behaviour, Vol. 23, No. 3, pp. 285-304.

Shibata, S., Suzuki, N. (2001), "Effects of indoor foliage plants on subjects' recovery from mental fatigue", North American Journal of Psychology, Vol. 3, No. 2, pp. 385-396.

Smith, A., Pitt, M. (2011), "Healthy workplaces: Plantscaping for indoor environmental quality", Facilities, Vol. 29, Nos. 3/4, pp. 169-187.

Smith, A., Tucker, M., Pitt, M. (2011), "Healthy, productive workplaces: Towards a case for interior plantscaping", Facilities, Vol. 29, Nos. 5/6, pp. 209-223. 
Sriprapat, W., Suksabye, P., Areephak, S., Klantup, P., Waraha, A., Sawattan, A., Thiravetyan, P. (2014), "Uptake of toluene and ethylbenzene by plants: Removal of volatile indoor air contaminants", Ecotoxicology and Environmental Safety, Vol. 102, pp. 147-151.

Taylor, A. (1996), "Respiratory irritants encountered at work", Thorax, Vol. 51, pp. 541-545.

Treesubsuntorn, C., Thiravetyan, P. (2012), "Removal of benzene from indoor air by Dracaena sanderiana: Effect of wax and stomata", Atmospheric Environment, Vol. 57, pp. 317-321.

Usha S., Mendell M.J., Shekhar K., Hotchi T., Sullivan D., Streufert S., Fisk W. (2012), "Is $\mathrm{CO}_{2}$ an indoor pollutant? Direct effects of low-to moderate $\mathrm{CO}_{2}$ concentrations on human decisionmaking performance", available at: http://ehp.niehs.nih.gov/1104789 (accessed 15 May 2016).

Wan J.W., Yang K., Zhang W.J., Zhang J.L. (2009), “A new method of determination of indoor temperature and relative humidity with consideration of human thermal comfort", Building and Environment, Vol. 44, No. 2, pp. 411-417.

Watson, D, (1992) "Correcting for acquiescent response bias in the absence of a balanced scale: An application to class consciousness", Sociological Methods Research, Vol. 21, No. 1, pp. 5288.

Wells, M. (2000), “At home with nature: Effects of 'Greenness' on children's cognitive functioning”, Environment and Behavior, Vol. 32, No. 6, pp. 775-795.

Wolkoff P., Kjaergaard S.K., (2007), "The dichotomy of relative humidity on indoor air quality", Environment International, Vol. 33, No. 6, pp. 850-857.

Wolverton, B.C., McDonald, R.C. (1982), "Foliage plants for removing formaldehyde from contaminated air inside energy-efficient homes and future space stations. National Aeronautics and Space Administration, Report No. TM-84674", available at: http://ntrs.nasa.gov/archive/nasa/casi.ntrs.nasa.gov/19860065907_1986065907.pdf (accessed 15 May 2016).

Wolverton, B.C., McDonald, R.C., Watkins Jr., E.A. (1984), "Foliage plants for removing indoor air pollutants from energy-efficient homes”, Economic Botany, Vol. 38, No. 2, pp. 224-228.

Wolverton, B.C. (1986), "Houseplants, indoor air pollutants and allergic reactions. National Aeronautics and Space Administration, Report No. TM-108057", paper presented at Otolaryngology, Orthodontics and Sleep Disorders Conference, 13-14 December, Pass Christian, MS, available at: http://ntrs.nasa.gov/archive/nasa/casi.ntrs.nasa.gov/19930072972_1993072972.pdf (accessed 15 May 2016).

Wolverton, B.C. (1988), "Foliage plants for improving indoor air quality. National Aeronautics and Space Administration, Report No. TM-108055", paper presented at National Foliage Foundation Interiorscape Seminar, July 19, Hollywood, FL, USA, available at: http://ntrs.nasa.gov/archive/nasa/casi.ntrs.nasa.gov/19930073015_1993073015.pdf (accessed 15 May 2016).

Wolverton, B.C., Johnson, A., Bounds, K. (1989), "Interior landscape plants for indoor air pollution abatement: Final Report. National Aeronautics and Space Administration, Report No. TM101768", available at: http://ntrs.nasa.gov/archive/nasa/casi.ntrs.nasa.gov/19930073077 1993073077.pdf (accessed 14 January 2008).

Wolverton, B.C. (1996), How to grow fresh air: 50 houseplants that purify your home or office, Weidenfeld and Nicolson, London. 
Wolverton, B.C., Wolverton, J.D. (1996), "Interior plants: Their influence on airborne microbes inside energy-efficient buildings", Journal of the Mississippi Academy of Sciences, Vol. 41, No. 2, pp. 99-105.

World Health Organisation (2010), "WHO guidelines for indoor air quality - Selected Pollutants", available at: http://www.who.int/indoorair/publications/9789289002134/en/ (accessed 15 May 2016).

Wyon D.P., Fang L., Meyer H.W., Sundell J., Weirsoe C.G., Sederberg-Olsen N., Tsutsumi H., Agner T., Fanger P.O. (2002), "Limiting criteria for human exposure to low humidity indoors", in Proceedings: Indoor Air: 2002, $9^{\text {th }}$ International Conference on Indoor Air Quality and Climate, pp. 400-405. Monterey, USA: International Academy of Indoor Air Science. Zuraimi M.S., Roulet C.A., Tham K.W., Sekhar S.C., Cheong K.W., Wong N.H., Lee K.H. (2006), "A comparative study of VOCs in Singapore and European office buildings", Building and Environment, Vol. 41, No. 3, pp. 316-329. 